\title{
Legal Satisfaction for the Creditors to Obtain a Return of the Credit From the Debtor
}

\author{
Ahmad Fauzi \\ Law Faculty, Universitas Muhammadiyah Sumatera Utara, Indonesia \\ edithsiltor@gmail.com
}

\begin{abstract}
In the process of granting credit by the bank to the debtor, a careful analysis has been done, but in the implementation there are often many factors that can cause the debtor to become unable to repay the credit received. So as to guarantee repayment of credit given to the debtor, the bank asks for a guarantee from the debtor in the form of property or personal collateral. In accordance with the nature of the collateral, the collateral in the form of land and buildings is generally preferred by banks because the value tends to be stable in the long run. Thus, it is necessary to have a regulation governing the guarantee of assets in the form of land and buildings so that an ease and certainty is obtained for the bank in obtaining repayment of loans given to debtors if in the future the debtor is apparently unable to repay these obligations. It is necessary to create a strong guarantee institution and be able to provide legal certainty for all parties with an interest in providing credit by banks, the government has enacted and enforced it. to impose Mortgage Rights cannot be withdrawn or cannot be terminated by any reason except because it has been implemented or has expired. The provisions are intended so that the encumbrance of the Underwriting Right is actually implemented so as to provide legal certainty for the holder and the giver of the Underwriting Right.
\end{abstract}

Keywords

legal certainty;

creditors; getting credit

returns; debtors

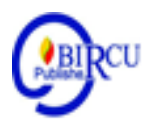

\section{Introduction}

The term credit comes from the Roman language "credere"1 which means trust. Therefore, the basis of lending is actually the trust or confidence of creditors that the debtor in the future has the ability to fulfill everything that has been promised. The term credit is not found in BW but is regulated in the Banking Principal Law No. 10 of 1998 (Banking Law), Article 1 point 11, where the definition of credit is stated as follows:

"Credit is the provision of money or bills that can be equated with that, based on the agreement of the loan agreement between the bank and other parties that require the borrower to repay the debt after a certain period of time with the provision of interest"

From the above formula it can be seen, that credit is a loan agreement between the bank as the creditor and the customer as the debtor. In this agreement the bank as a lender believes in its customers that within the agreed time period the customer will pay off the credit

\footnotetext{
${ }^{1}$ Miriam Darus Badrulzaman, Perjanjian Kredit Bank, Alumni, Bandung, 1978, p. 19
} 
provided by the bank. This grace period between giving and receiving back achievement is an abstract thing, which is hard to touch, because the period between giving and receiving achievement can run for several months, but can also run for several years. ${ }^{2}$

The Banking Act of 1998 does not refer to any type of credit. However, in the practice of banking loans that have been given to its customers can be seen from several aspects, namely as follows:

1. time period

2. uses

3. usage

4. sectors financed ${ }^{3}$

"Usually in a loan and loan agreement, the creditor asks the debtor to provide collateral in the form of a number of assets for the purpose of paying off the debt, if after the agreed period, the debtor does not pay off. In accordance with its purpose, collateral items must be owned by creditors, because the debt and credit agreement is not a sale and purchase agreement that results in the transfer of ownership of the goods. Collateral is used to pay off debt, in accordance with applicable regulations, that is, collateral is sold at auction. The result is to pay off debts, and if there is still the remainder returned to the debtor.

Collateral items do not always belong to the debtor, but the law also allows third party goods, provided that the party relinquishes the goods as debt collateral.

The granting of the Collateral Agreement is always followed by the agreement that preceded it, namely the debt and credit agreement called the principal agreement. There is no guarantee agreement without the principal agreement. Because the guarantee agreement cannot stand alone, but always follows the main agreement. If the main agreement ends, the guarantee agreement also ends. There is no way anyone would be willing to guarantee a debt, if there was no debt itself. The nature of the agreement is called accessoir. ${ }^{4}$

In order to be able to make a guarantee agreement, the underlying agreement must be clearly set out about the existence of the promise of guarantee. With these promises being the source of the collateral agreement required by lenders and lenders. So making a guarantee agreement is one of the implementations of the underlying agreement.

In the Criminal Code does not specify the existence of a general and special guarantee, but from a number of existing rules it is known what is a general and specific one. General guarantees are set out in Article 1131 of the Criminal Code, which reads:

"All proprietary rights of a debtor, whether existing or new, will become a liability to any individual alliance"

Debtors in this case are passive enough, not needing to make guarantees, as their alliances are already regulated by law. In the absence of an agreement entered into by the parties, the concurrent creditors all jointly obtained the general guarantee provided by the law. ${ }^{5}$

So in this general guarantee, all the assets of the debtor are a guarantee to the creditors irrespective of who the lender made the alliance with. All creditors have the same rights, but

\footnotetext{
${ }^{2}$ Edy Putra Tje'Aman, Kredit Perbankan Suatu Tinjauan Yuridis, Liberty, Jokyakarta, 1989, p. 10

${ }^{3}$ Gatot Supramono, Perbankan dan Permasalahnnya Perbankan Dan Permaslahannya, Djambatan, Jakarta, 1996, p. 45

${ }^{4}$ Gatot Supramono, Perbankan Dan Permasalahannya, Djambatan, Jakarta, 1996, p. 75

${ }^{5}$ Sri Soedewi Masjchoen Sofwan, Hukum Jaminan di Indonesia Pokok-Pokok Hukum Jaminan dan

Jaminan Perorangan, Liberty, Jogyakarta, 1980. p. 45
} 
the repayment of debt is not evenly distributed from the sale of the goods. According to Article 1132 of the Criminal Procedure, the proceeds of the sale of the goods are apportioned by equilibrium, that is, to the creditors of each of the creditors, unless the lender has the right to advance.

Accordingly, Sri Soedewi Masjchoen Sofwan said that such guarantees in the practice of credit (debt collateral agreement) did not satisfy the lender, creating less security and security for the credit given. ${ }^{6}$

Under this special guarantee, the debtor promises to the lender a specific item of credit specifically for the debtor's debt guarantee. In addition to being goods, specialty guarantees can also be people. Although it can be a person, it is ultimately the property of the person in question that can be confiscated and sold for auction for debt.

As with the general guarantee agreement, in order to make a special guarantee agreement, the agreement must also be promised in that regard. It was recently made its accessoir agreement which is an accessory. There are a number of specific guarantees contained in the Penal Code. The specific warranties set forth in the Criminal Code are:

1. Mortgages

2. Mortgage

3. Suspension (Borgtocht)

While the specific guarantees set forth in the Penal Code are contained in Koninklijk Besluit, they are:

1. Credietverband

2. Oogstverband

In addition there are still guarantees outside of the Penal Code that arise in practice and then recognize the jurisprudence of fiduciarie eigendoms overdracht. Of these types of mortgages and credietverband are guarantees of immovable goods. Mortgages, oogstverband and fiduciarie eigendoms overdracht as collateral for moving goods. While suspension is an individual guarantee.

In Indonesia the forms of securities regulating the securities exchange, between the debtor and the lender are regulated by law. These warranties are:

1. Mortgages, which can be charged on non-moving objects;

2. Credietverband, which can be charged on immovable things but in this case only certain lenders can charge the credietverband on immovable property of the debtor;

3. Pawn rights, rights that may be imposed on moving objects, including in this case fiduciary. Fiducia arises based on the needs caused by the development of law;

4. Borgtocht, where a third party expresses its willingness to pay the debtor's debt when the latter is unable to pay its obligations.

With the enactment of the Act, the provisions on the land rights of the surety, previously applicable, especially the provisions on mortgage and credietverband except for the execution of the mortgage as long as the provisions of the Act have been repealed.

In fact, there are many other rules which, although not explicitly stated in the lex posterior principle of a priori derivative derogation, do not apply, namely, the old rules which are the implementation of the provisions of Article 51 jo of Article 57 of the Agrarian Laws now enshrined in Article 5 of the Constitution . 
Therefore, with the enactment of the UUHT there has been a change in the law in the field of law of securities, in particular regarding the parcel of land as the guarantee of Mortgage rights law. ${ }^{7}$

\section{Discussion}

\subsection{Position of Creditor as Holder of Mortgage Rights}

Law number 4 of 1996 concerning Mortgage Rights (UUHT_ gives a privileged position to creditors holding Mortgage Rights. In the explanation of UUHT number 3 it is stated that the Mortgage Rights as a strong land tenure security institution with the following characteristics:

\section{a. Giving Priority or Position to the Holder, Known as "Droit De Preference"}

This feature is affirmed in Article 1 number 1 UUHT which reads as follows:

"... to pay off certain debts, which give certain creditors a priority over other creditors "

Likewise, the provisions of Article 20 paragraph (1) of the UUHT which states that if the debtor fails to promise, the creditor holding the Underwriting Right has the right to sell the object as collateral through a public auction according to applicable regulations and to repay his receivables from the proceeds of the sale, with the right to overtake from other creditors who are not holders of Underwriting Rights or creditors who hold Underwriting Rights with lower rank. This privilege certainly does not belong to the creditor not the Mortgage holder.

This priority certainly does not reduce the state receivables preference according to the provisions of applicable law (as explained in the general explanation of number 4 UUHT). But in this general explanation it is not stated whether the State receivables referred to are limited to the State Receivables relating to the object Mortgage concerned only, or regarding all State receivables that are the obligations of the debtor concerned.

Creditors who hold Mortgage Rights that are not BUMN or government agencies such as Private Banks will feel treated unfairly if the scope of what is included in state receivables is not limited. Because as stated by the Chairperson of the State Receivables and Auction Affairs Agency (BUPLN) Adolf Warrow, what is meant by state receivables in this UUHT is not limited to tax only, but also includes all state receivables as according to Law Number 49 Prp of 1960 concerning the Affairs Committee Putang Negara. According to Adolf Warrow, the priority between tax and bad debt from other SOEs based on Law Number 49 Prp of 1960 is not differentiated is submitted to the BUPLN. Based on the provisions of article 1137 of the Indonesian Criminal Code and because in Law Number 49 Prp of 1960 concerning the State Receivables Affairs Committee, no provisions were found that determine the prioritization of state receivables from pledges and mortgages. Thus, to prioritize Mortgage Rights, Sutan Remy does not state that Adolf Warrow's opinion cannot be accepted. ${ }^{8}$

\section{b. Always Follow the Object Guaranteed in the Hands of Whoever the Object is}

The feature known as "droite de suite" is affirmed in Article 7 of the UUHT. Even if the object of the mortgage has been transferred to another party, the creditor of the mortgage right still has the right to sell it through a public auction, if the debtor fails to promise.

${ }^{7}$ Satrio, Op.,cit, p. 9 


\section{c. Fulfill the Principle of "Specialty" and "Publicity", So That It can Bind Third Parties and Provide Legal Certainty to the Parties Concerned}

Droit de preference and droit de suite as a privilege given to creditor holders of Underwriting Right can clearly harm other creditors and buyers of the Underwriting Right object concerned, if the Underwriting Right burdens the object which is used as collateral for paying off the creditor hole, it is unknown to them. So for the legitimate imposition of Underwriting Rights it is required, that it must be clearly stated which receivables and to what amount is guaranteed as well as which items are used as collateral. This is called fulfillment of speciality requirements, namely the identity of holders and givers of Mortgage and their respective domiciles must be included in the Deed of Granting the Mortgage Rights concerned.

\section{d. Easy and Certain Execution of the Execution}

As stated above, if the debtor fails the promise of the creditor, the Underwriting Right holder has the right to auction off objects which are used as collateral for the payment of his receivables.

1. Can be valued in money, because debt guaranteed in the form of money;

2. Including the rights registered in the public register, because they must meet the requirements of publicity;

3. Has transferable nature, because if the debtor fails to promise the object used as collateral will be sold publicly and;

4. Requires appointment by law. In connection with the existence of these requirements, what is the object of the Underwriting Right is as mentioned in Article 4 in conjunction with Article 27 of the UUHT:

a) Objects of Mortgage that are designated by the Basic Agrarian Law, namely: Ownership Rights, Business Use Rights and Building Use Rights;

b) Objects of Mortgage designated by Law No. 16 of 1985 concerning Flats:

- Flats that stand on land for ownership, use rights for building and use rights granted by the state and;

- Proprietary rights over Flats that are built on land, the rights mentioned above.

c) Objects of Mortgage designated by the UUHT: The right to use state land which according to the provisions in force must be registered and by its nature can be transferred.

Mortgage rights are also given the nature of material rights. The nature of material rights is:

1. Having a lanagsung relationship with / on certain objects which in relation to the guarantee right, the object is the property of the Underwriter Right;

2. Can be maintained or addressed to anyone (everyone);

3. Having the property of droit de suite, meaning that the right follows the object in the hands of whoever that object is;

4. The older one has a higher position;

5. Can be transferred / to others;

The material rights with the characteristics as mentioned above, especially the characteristics of droit de suite which follows the object into the hands of whoever it moves, gives the creditor a better / stronger guarantee rights compared to personal rights, because that right follows the object. And if the right follows his object in the 
hands of whoever he moves to, then that is tantamount to saying that the right can be directed to anyone, not certain of the person, whoever, in whose hand the creditor finds the guarantee.

Underwriting rights according to Article 2 paragraph (1) of the UUHT have the nature of not being divided. This means that the Underwriting Right imposes a whole object of the Underwriting Right and every part of it. The partial payment of the guaranteed debt does not mean that the object of the Underwriting Right is free from the burden of the Underwriting Right, but the Underwriting Right still imposes all the Underwriting Right objects for the debt side that has not been repaid. This principle is taken from the principles that apply to mortgages as mentioned in Article 1163 of the Indonesian Criminal Code. Based on this nature, then a partial roya on Mortgage becomes impossible.

However, if the parties want, then the nature can not be divided into Mortgage Rights can be distorted, namely by pledging it firmly in APHT. Because if it is not like that, the principle of Underwriting Right still cannot be divided. However, this deviation can only be done as long as the following conditions are met:

1. The Underwriting Right is imposed on several land rights;

2. Repayment of guaranteed debt is done by installments in the amount equal to the value of each land right that is part of the Underwriting Right object, which will be freed from the Underwriting Right, so that the Underwriting Right will only burden the remaining object of the Right to protect the remaining debt which has not been paid off.

Our National Land Law is based on Customary Law in relation to buildings and plants using the principle of horizontal separation. According to this principle buildings and plants that are on the ground are not part of the land concerned. Then legal actions regarding land do not automatically include buildings and / or plants on it. So that the imposition of Mortgage Rights on objects related to the land only occurs if it is expressly stated in the APHT deed concerned. If that is not stated explicitly (explicitly), the Mortgage only happens to the land. This is in accordance with the principle of horizontal separation adhered to by the National land law.

While the Penal Code adheres to the principle of attachment, this is reflected in the provisions of article 1165 of the Penal Code which stipulates that every mortgage includes everything that is united with the object because of growth or development. In other words, without having to be agreed upon in advance, all objects related to the new land will be in the future, legally also burdened with mortgages that have been previously charged over the land rights that are the object of the Mortgage.

The establishment of the UUHT regarding the imposition of horizontal separation which is not absolute invites polemic. Sutan Remi is of the opinion that at the same time he proposes that a separate law be made regarding the right to guarantee property related to land. In this law to determine the existence of objects relating to land that is required and which are not required to be registered, at least it is possible for the owner to be able to register these objects if desired so that their rights are protected or want to be burdened with security rights . For registered persons, certificates of rights to objects which constitute a unit or that do not constitute a unit with the relevant land are registered. Of course, because the desired guarantee rights must be able to apply like or bind a third party, of course only items that are registered and have certificates can be burdened with the intended guarantee rights. Thus, objects related to land can be burdened with a security right even if the land is not burdened 
with Hank Dependents. If the aforementioned law is issued, the application of the principle of horizontal separation of land can be absolute and can comply with the principle (consistently)

\subsection{Clear Appointment of Debt Guaranteed}

Article 11 paragraph 1.c of the UUHT states that in the APHT must be stated "clearly designating the debt or debt guaranteed".

While according to Article 3 paragraph (1) of the UUHT, what is meant by guaranteed debt can be in the form of:

a. existing debt, or;

b. the agreed amount of debt, or;

c. at the time the application for selecting Underwriting Rights can be determined based on:

1. a debt-receivable agreement, or;

2. other agreements that give rise to the related debt-related relationship.

For banks, it is almost impossible to determine a definite amount of credit. For investment loans, the amount of credit will always decrease from time to time if the debtor regularly makes credit installments according to the installment schedule. However, if then the credit is no longer paid in installments and interest is not paid, the amount of credit will increase again in line with the charging of interest. While if the credit is in the form of a Current Account, the credit will fluctuate from time to time following the time and amount of deposits and withdrawals of the debtor's credit. So with the provisions of Article 3 paragraph (1) of the UUHT, there will be no more debate regarding the amount of debt that must be paid back by the debtor at the time of execution of the Mortgage.

In SKMHT or APHT it is sufficient if it is stated that the amount of credit is the maximum amount of credit plus costs and interest that will still be calculated by the bank until the time the mortgage is executed.

\subsection{Mortgage Certificate Has Executive Power}

One of the characteristics of a strong mortgage is young and certain in the execution of its execution, if the debtor fails to promise. The ease and certainty of the execution of the execution can be seen by providing easier ways of execution than through a lawsuit such as an ordinary civil case.

For this execution, UUHT provides 2 (two) ways, namely:

a. As regulated in Article 6 of the UUHT, and

b. Parate Executie, regulated in article $224 \mathrm{RIB}$ and Article $258 \mathrm{RRBg}$, as affirmed in Article 26 UUHT.

In connection with the parate executie, the Underwriting Right Certificate that serves as proof of the existence of the Underwriting Right, is attached with the words "FOR THE SAKE OF JUSTICE UNDER THE ALMIGHTY GOD" to provide the same executive power with a court decision that has legal force permanent.

Article 6 of the UUHT provides the right for the first Mortgage Holder to sell the object of the Mortgage on his own power through a public auction and to take the settlement of the receivables from the proceeds of the sale. If there is more than one creditor who holds the Underwriting Right, the authority lies with the first Underwriting Right Holder. Sales must be made through a public auction conducted by the Auction Office. And in carrying out the sale of the Underwriting Right object and taking repayment of the receivables, the special authority that exists on the creditor who holds the Underwriting Right is "droit de preference" 
and droit de suite ". Article 6 This UUHT is strengthened by the promise referred to in Article 11 paragraph (2) letter (e) of the UUHT, namely the promise that the first Mortgage Holder has the right to sell on his own power the Mortgage object object if the debtor is in default. This is the shortest procedure for execution, because creditors do not need to submit requests for execution to the court or the Chair of the District Court. In order to be able to use the authority to sell the Underwriting Right object without prior approval from the debtor, the debtor's promise referred to in Article 11 paragraph (2) is required. And the promise must be included in the relevant APHT.

But in carrying out the creditor's authority which prior to the enactment of the UUHT is obtained based on promises given under Article 1178 paragraph (2) of the Indonesian Criminal Code, parate executies. This means that the mortgage right holders need not only obtain approval from the mortgage rights provider, but also do not need to ask for a determination from the local court if they are going to execute the mortgage right which is a guarantee for the debtor's debt in the case of a defaulted debtor. Mortgage holders can immediately come and ask the Head of the Auction Office to auction the object of the Mortgage in question.

The right to sell the object of the Underwriting Right on its own power is one embodiment of the priority position that is owned by the Underwriting Right Holder, or by the first Underwriting Right Holder in the event that there is more than one Underwriting Right Holder.

In Article 20 paragraph (2) of the UUHT it is determined that there is a possibility of selling collateral for loans under the hand and not through a public auction. This method is possible as long as there is an agreement between the debtor (the Underwriter) and the Bank or Creditor (the Underwriter) in the hope that the highest price will be obtained to benefit all parties. But the UUHT requires that several conditions are met:

a. The sale can only be done after 1 (one) month has passed since written notification by the Debtor and / or Creditors / Banks to the parties concerned;

b. It is announced in at least 2 (two) newspapers circulating in the area concerned and / or local amassa medi, and there are no parties to object.

With the enactment of the UUHT, then at the stage of signing the Deed of Purchase, the debtor is also possible to sign an APHT on the portion of land he bought, even though at that time the land certificate was not yet reversed by name on behalf of the debtor concerned.

The encumbrance process as mentioned in numbers 1 and 2 above can lead to legal uncertainty. Because the Underwriting Right was born on the date of the Underwriting Rightland book. For the date of the Land Book of the Underwriting Right, a certain date has been determined as the date of the land book, which is the seventh day from the day that the requirements for registration in the form of registration are fulfilled. Then as proof of Mortgage Rights, the Land Office issues a Mortgage Right certificate.

\section{Conclusions}

The bank in providing credit requires a guarantee, where the function of the guarantee is to expedite and secure the relevant credit. This has caused banks to need legislation that can provide certainty and legal protection for banks.

To answer this need, a UUHT was born, so that banks could obtain legal certainty of the collateral rights to the land granted by the debtor to the bank. 
a. Mortgage rights give priority to creditors holding Mortgage Rights. This means that if the debtor fails to promise, the creditor of the Underwriting Right Holder can sell through the public auction of land which is used as collateral according to the provisions stipulated by the UUHT (the principle of droit de preference);

b. The Underwriting Right will not end even if the object of the Underwriting right is transferred to another party due to any reason (droit de suite principle);

c. The Mortgage Certificate has the same executive power as a court decision that has permanent legal force.

The UUHT does not only pay attention to the interests of the creditor but also the interests of the debtor because the law prohibits giving authority to the debtor to have the object of mortgage if the debtor fails to promise.

UUHT is very accommodating to the needs of the banking world because:

a. The Mortgage can be used to guarantee the new debt in the future regarding debt as a result of the disbursement of a bank guarantee or to collect the debt as a result of charging interest on the principal and other charges which can only be determined later.

b. Mortgage can guarantee more than one debt. Each of these receivables can be guaranteed with only one Mortgage Right for all creditors which is done with one APHT, because the provisions of the UUHT provide the possibility of collateral in the form of one Mortgage to several creditors on a pari passu basis.

Constraints that can affect the legal certainty of the enactment of the UUHT, namely on land that has not been certified (still in the process of requesting rights or the certificate has not been reversed name or diroya) because the Underwriting Right certificate as proof of the existence of the Underwriting Right cannot be issued by the Land Office so it causes uncertainty law because the Bank is unable to prove that he is the holder of the Underwriting Right.

\section{References}

Arie S Hutagalung, Serba Aneka Masalah Tanah Dalam Kegiatan Ekonomi, Cet. 1, Badan Penerbit Fakultas Hukum UI, Jakarta, 1999

Edy Putra Tje'Aman, Kredit Perbankan Suatu Tinjauan Yuridis, Liberty, Jokyakarta, 1989

Gatot Supramono, Perbankan dan Permasalahnnya Perbankan Dan Permaslahannya, Djambatan, Jakarta, 1996

H. Yudo Paripurno, Pengaturan dan Pelaksanaan Surat Kuasa Memasang Hipotik (SKMH) Dalam Kaitannya Dengan Undang-Undang Hak Tanggungan, Makalah disampaikan di Kampus UI Depok, 9 Mei, 1996

J. Satrio, Hukum Jaminan, Hak Jaminan, Kebendaan, Hak Tanggungan, Citra Aditya Bakti, Bandung, 1997

Miriam Darus Badrulzaman, Perjanjian Kredit Bank, Alumni, Bandung, 1978

Sri Soedewi Masjchoen Sofwan, Hukum Jaminan di Indonesia Pokok-Pokok Hukum Jaminan dan Jaminan Perorangan, Liberty, Jogyakarta, 1980

Sutan Remy Syahdeini, Hak Tanggungan Asas-Asas, Ketentuan-Ketentuan Pokok Dan Masaalah Yang Dihadapi Oleh Perbankan, cet 1, Alumni, Bandung, 1999

Undang-Undang No. 4 Tahun 1996 Tentang Hak Tanggungan Atas Tanah Beserta BendaBenda Yang Berkaitan Dengan Tanah ("UUHT") 